\title{
SITES AVAILABILITY FOR MINIMALIZING AND SOIL-CONSERVATION TILLAGE OF SOILS IN SLOVAKIA
}

\author{
JOZEF VILČEK ${ }^{1}$, KAROL KOVÁČ ${ }^{2}$ \\ ${ }^{1}$ Soil Science and Research Institute Bratislava \\ ${ }^{2}$ Honorary member of Slovak Academy for Agricultural Sciences, Nitra
}

VILČEK, J. - KOVÁČ, K.: Sites availability for minimalizing and soil-conservation tillage of soils in Slovakia. Agriculture (Pol’nohospodárstvo), vol. 57, 2011, no. 2, pp. 68-75.

There is an alternative technology of traditional agricultural soil processing, so called minimalizing cultivation, which is based on reduction of some operating processes used in common. It is possible to perform this technology only in particular soil conditions. Total land area of sites, which are avail-able for the application of minimalizing cultivation is about 693 thousand hectares, which presents approximately $28 \%$ of agricultural and $48 \%$ of arable soils. $60 \%$ of this land area occurs in the maize production area and $39 \%$ in the sugar beet production area, thus in the most favourable agricultural local-ities regarding climate and soil. According to the administrative structuring of Slovakia $43 \%$ of agricultural soils suitable for minimalizing technologies occurs in Nitra district and about $27 \%$ in Trnava district. Identification of areas, suitable for such technologies application, is possible by the information databases of Soil Science and Conservation Research Institute, which have been elaborated for this purpose in geographic and informative systems. Regarding input parameters, they were chosen as follows: climatic conditions of given locality, steepness, depth, stoniness and soil texture.

Key words: minimalizing soil cultivation, soil parameters, soil availability, soil regionalization, agricultural productive areas

\section{INTRODUCTION}

Minimalizing soil cultivation presents treatment, which reduces the number of mechanic operations, including seeding, nutrition and plant protection (Birkás 2002; Hůla \& Procházková 2008; Kováč et al. 2010). From ecological point of view this kind of cultivation is the way how to keep soil fertility in the long term and to protect soil properties from degradation (soil erosion and carbon sequestration). These technologies are integrated into the group, simplified ways of soil cultivation" in practice. The term minimalizing soil cultivation includes soil protective technologies as well. These are characterized by more than $30 \%$ of soil surface covered by the plant remains of preceding crop and intercrop (Macák et al. 2008; Logsdon
\& Karlen 2004). Besides ecological benefits as, e.g. higher content of Cox, Nt and higher content of microbial carbon, technologies enable better soil moisture management and offer economic effects (Kováč et al. 2005; Sobocká et al. 2010; Švančárková \& Lehocká 2002; Žák et al. 2002). Minimalizing and soil protective technologies are suitable in drier areas, for soils with natural regenerative abilities of physical state and where water and wind erosion occurs. It is necessary to mellow deeply the compact soils before minimalizing technology application and this loosing must be intentionally repeated after 3 or 4 years (Hůla \& Procházková 2008). An organic part of minimalizing is also presence of dynamic integrated systems of plant nutrition and protection (Hůla \& Procházková 2008; Rủžek et al. 2000). Technologies make use of biological (GMO)

prof. Ing. Jozef Vilček, PhD., Soil Science and Conservation Research Institute, Faculty of Humanities and Natural Sciences University of Prešov, 08001 Prešov, Raymanova 1, Slovak Republic. E-mail: j.vilcek@vupop.sk

doc. Ing. Karol Kováč, PhD., Honorary member of Slovak Academy for Agricultural Sciences, Nitra, Slovak Republic. E- mail: karol.kovac1@gmail.com 
and technical progress. This is a multifunctional technology permitting precision placement of fertilizer, (so called PPF systems, for example seeders HORSCH PPF), application of specific herbicides and graminocides, plough-share, plate, chisel cultivators and seeders for No-till crop production (direct seeding into the rough soil, Kováč et al. 2010; Sobocká et al. 2010).

Growing plants without farm animals (without livestock production) utilizes positive soil protective effect of mulch. Mulch can be obtained from two sources. The first source is represented by the plant rests of the preceding crops and the other presents rests of frost killed intercrop. More significant efficiency of erosion reduction occurs at minimal $30 \%$ soil covering by plant rests. Seeding into the plant rests of the preceding crops mulch is under consideration if legume, namely soya beans and winter rape, is grown and they are followed by winter crop (Birkás 2002; Hůla \&
Procházková 2008; Heege \& Vosshenrich 2000; Kováč et al. 2010). Seeding into the mulch biomass formed by the rests of frost or chemically killed intercrop is one of the main ways of protective cultivation when spring crop (potatoes, sugar beet, sunflower, maize, peas and, where conditions are suitable, barley as well) is based as overgrowth.

There is an absence of detailed knowledge on soil-ecological conditions for intentionally utilization of above mentioned and characterized technologies in scientific and professional literature in Slovakia. The first categorization of agricultural land regarding minimalizing cultivation point of view was elaborated by Juráň et al. in 1979. The present level of soil parameters knowledge and existing soil databases, their occurrence and characteristics based on principles of geographic informative systems (GIS) enables more particular and more sophisticated results. All these as-

$\mathrm{T}$ a

Soil limits for minimalizing soil cultivation technologies application

\begin{tabular}{|c|c|}
\hline Primary limits & Parameter \\
\hline Altitude & - to $350 \mathrm{~m}$ altitude (exceptionally more) \\
\hline Annual total rain amount & - to $600 \mathrm{~mm}$ \\
\hline Average annual air temperature & - over $8^{\circ} \mathrm{C}$ \\
\hline Soil granularity & - medium heavy soils - loamy and sandy-loamy soils $(25-45 \%$ of clayey particles $)$ \\
\hline Topsoil depth & - more than $0.30 \mathrm{~m}$ \\
\hline Soil skeletally & - seldom appearance of $10 \mathrm{~mm}$ particles \\
\hline Soil steepness & - soils to $12^{\circ}$ \\
\hline Additional limits & Parameter \\
\hline Water content & - non-water-logged soils \\
\hline Water move & - good infiltration \\
\hline Soil reaction & - $\mathrm{pH}$ higher than 5.6 \\
\hline Humus content & - about 2.5 in topsoil \\
\hline Sorptive complex saturation & - well to fully saturated \\
\hline Biological activity & - good \\
\hline Thermal capacity & - cool soils are inappropriate \\
\hline Soil compactness & - non-compact subsoil \\
\hline Agronomical requests & $\begin{array}{l}\text { - proper seeding technique, suitable mechanization able to work in plant rests on the } \\
\text { ground surface, proper organization of the overgrowth and choice of good variety }\end{array}$ \\
\hline Nutriment supply in the soil & - good and higher \\
\hline
\end{tabular}

(Source: Vilček: In Kováč - Nozdrovický - Macák et al. 2010) 
pects were considered when the task of the presented contribution was investigated and processed.

\section{MATERIAL AND METHODS}

It is obvious, that not each kind of soil, site, locality is suitable for reduction of applicated agricultural techniques, or classical soil cultivating technologies. Today, even without expensive experiments and trial and error method, it is possible, relatively accurately, to locate soils suitable for such technologies application and soils which are absolutely unsuitable for it. This is enabled by the detailed pedological research of agricultural soils, which has a very long tradition, lasting for many years, in Slovakia. Soil limits for this way of farming has been defined on the basis of the research.

Primary limits regard determining physical soil parameters predominantly, which significantly predetermine or exclude particular site for minimalizing and soil protective cultivation. Parameters boundary values (Table 1) for these limits were defined to specify soil suitability for such technologies explicitly. Methodical base of choice of individual parameters were practical experiences and knowledge from realization of such technologies in practice (Miština \& Kováč 1993; Hůla \& Procházková 2008; Šimon et al. 1989; Šimon et al. 1999).

Spatial identification and soil quantification of soil corresponding the given parameters was processed on the basis of informative layer extension so called site soil-ecologic unit (BPEJ) of Slovakia in geographic informative system Arc Info. The system of soil evaluation in Slovakia (Džatko \& Sobocká 2009) offers spatial characteristics of agricultural soils which regard climatic region, type of soil, steepness, exposition, depth, soil gravely and stony and granularity as well. Site soil-ecologic units in a vector form using GIS enable easy categorization of soils, or areas according to mentioned parameters.

Climatic parameters which limit using of minimalizing technologies, related to the parameter of altitude were derived from database of detailed climatic regions (Džatko \& Sobocká 2009). For limiting climatic region was chosen region 05 , characterized as - relatively warm, dry, basin-like, continental. Regions with worse climatic conditions were for application of minimalizing technologies excluded.

Our report regards requirements resulting from

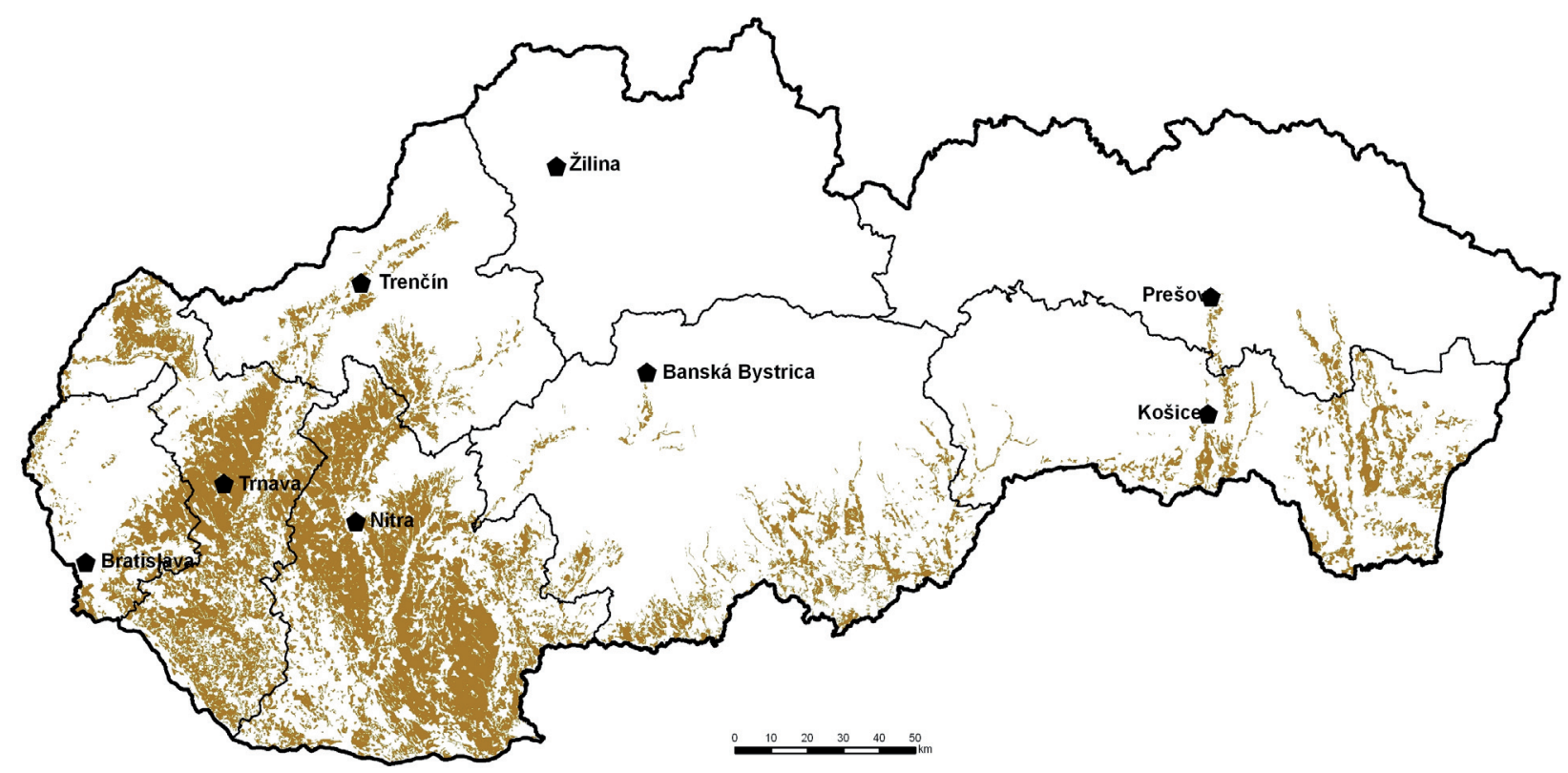

Fig. 1. Agricultural soils suitable for application of minimalizing technologies 
Regulation of Council EC GAEC 73/2009 (Good agricultural and environmental conditions) and Crosscompliance specified by measurements on soil protection against erosion.

Regarding proper agricultural practice as arable land can be used localities on the slope to $12^{\circ}$ exclusively, which is presented by soils in the medium slope in land evaluation system. As minimalizing technologies are realized mostly in arable soils, the given steepness limit was also accepted.

Reaching good harvest of the grown crops required, except another factors, soils with a good texture, deep soils not gravelly or stony. For these reasons, soils which are the most suitable for application of minimalizing technologies are loamy, in land evaluation system called medium heavy, soils medium deep and depth (above $0.3 \mathrm{~m}$ ) and soils without stony (content of skeleton to the depth $0.6 \mathrm{~m}$ below $10 \%$ ).

Presented parameters, identified by site soil-ecologic units gave input parameters for modelling of suitability of agricultural landscape for application of minimalizing soil cultivating technologies.

Additional limits present chemical and biological soil parameters, which can significantly influence a suitable choice of the site as well. As these parameters are mostly time variable and there is not a suitable spatial database on their occurrence, they were not considered in our method. The suitability of a particular site limits next soil, climatic, agronomic and anthropic parameters. It is noteworthy to mention, e.g. influence of the preceding crop, fertilizing, site weediness, site surface condition etc.

Presented limits and parameters were identified and generated from the existing databases and informative systems on soils of Slovakia, which are managed by Soil Science and Conservation Research Institute Bratislava. The advantage of these systems is their digitalization and availability in the vector form, helping thus the selection of chosen limits and parameters using modern classificatory programs and geographic informative systems (GIS).

\section{RESULTS AND DISCUSSION}

The most suitable regions for application of minimalizing soil cultivating technologies, from regional geomorphologic classification of Slovakia (Mazúr \& Lukniš 1978), are sites in Danubian Lowland and Hillyland, Chvojnická Hillyland, Považské Valley, Hornonitrianska Basins, South Slovak Basins, Košice Basins and East Slovak Lowland.

Using geographic informative systems, site databases on soils in Slovakia and specialized layers of soil parameters in vector form, total land area of sites suitable for application of minimalizing soil cultivating was determined in number 693 thousand hectares, which presents about $28 \%$ agricultural soils and $48 \%$ arable lands (Fig. 1).

$\mathrm{T}$ a b 1 e 2

Contribution of soils suitable for minimalizing soil cultivating technologies in productive regions of Slovakia in \%

\begin{tabular}{|l|c|c|c|c|}
\hline \multirow{2}{*}{ Productive region } & \multicolumn{3}{|c|}{ Contribution of soils suitable for minimalizing soil cultivating technologies } \\
\cline { 2 - 5 } & $\begin{array}{c}\text { from all agricultural } \\
\text { soils of Slovakia }\end{array}$ & $\begin{array}{c}\text { from suitable } \\
\text { agricultural soils } \\
\text { of Slovakia }\end{array}$ & $\begin{array}{c}\text { from agricultural soils } \\
\text { in a region }\end{array}$ & from arable regions \\
\hline Maize & 16.9 & 60.0 & 45.9 & 55.8 \\
Beet & 11.1 & 39.1 & 48.9 & 76.2 \\
Potato & 0.4 & 0.9 & 1.0 & 3.2 \\
Mountainous & - & - & - & - \\
\hline
\end{tabular}


Characteristics of the soils suitable for minimal processing according to productive regions

Maize productive region - $60 \%$ of total agricultural soils area in Slovakia suitable for application of minimalizing technologies belongs to this region. Within the frame of this productive region agricultural soils suitable for application of minimalizing technologies presents about $46 \%$. Dominant soil type suitable for these technologies are Chernozems, presenting $45.8 \%$ from the total acreage and they are followed by Fluvisols (19.4\%), Haplic Luvisols (12.8\%) and Mollic Fluvisols (12.1\%). Regarding granularity these are medium heavy soils - loam. $84.2 \%$ of such soils occur in lowland. These soils are deep without skeleton. Dominant soil-climatic region $(64.3 \%)$ is very warm, very dry lowland.

Beet productive region $-39.1 \%$ of total agricultural soils area in Slovakia suitable for application of minimalizing technologies belongs to this region. Within the frame of this productive region agricultural soils suitable for application of minimalizing technologies presents about $49 \%$. Dominant soil type suitable for these technologies are Haplic Luvisols, presenting $42.6 \%$ from the total acreage and they are followed by Fluvisols (19.6\%), Regosols (13.7\%) and Chernozems (11.4\%). Regarding granularity these are medium heavy soils - loam (95.2\%) and partially sandy-loam (4.8\%). 58.7\% of such soils occur in lowland, $31.4 \%$ in moderate slopes. These soils are deep without skeleton. Dominant soil-climatic region $(40.6 \%)$ is warm, very dry lowland.

Potato productive region $-0.9 \%$ of total agricultural soils area in Slovakia suitable for application of minimalizing technologies belongs to this region. Within the frame of this productive region agricultural soils suitable for application of minimalizing technologies presents about $1 \%$. Dominant soil type suitable for these technologies are Fluvisols, presenting 58.6\% from the total acreage and they are followed by Albic Luvisols (26.3\%) and Haplic Luvisols (12.3\%). Regarding granularity these are medium heavy soils - loam (79.5\%) and partially sandy-loam (20.4\%). $74.3 \%$ of such soils occur in lowland, $15.1 \%$ in moderate slopes. These soils are deep without skeleton. Dominant soil-climatic region (73.1\%) is relatively warm, dry, basin-like, continental.

Mountainous productive region - soil-climatic conditions in this productive region are not suitable for application of minimalizing technologies. It does not mean that this way of cultivation is not possible to application. If there are specific conditions, mostly regarding so called soil protection cultivation technologies (e. g. soil protection from erosion), it is possible to applied such systems for a short time.

Contribution of soils suitable for minimalizing soil cultivating technologies in productive regions of Slovakia is given in Table 2 .

Characteristics of the soils suitable for minimal processing according to the territorial administrative units

District of Banská Bystrica - 9.4\% of total agricultural soils area in Slovakia suitable for application of minimalizing technologies belongs to this district. Within the frame of this district agricultural soils suitable for application of minimalizing technologies presents about $15.5 \%$. Dominant soil type suitable for these technologies are Fluvisols, presenting 37.6\% from the total acreage and they are followed by Haplic Luvisols (21.4\%), Albic Luvisols (21.2\%). Regarding granularity these are medium heavy soils - loam (89.6\%) and partially sandy-loam (10.4\%). 64.9\% of such soils occur in lowland, $23.0 \%$ in moderate slopes. These soils are deep and without skeleton. Dominant soil-climatic region $(55.6 \%)$ is warm, very dry, basinlike, continental.

District of Bratislava $-5.3 \%$ of total agricultural soils area in Slovakia suitable for application of minimalizing technologies belongs to this district. Within the frame of this district agricultural soils suitable for application of minimalizing technologies presents about $39.0 \%$. Dominant soil type suitable for these technologies are Chernozems, presenting 38.9\% from the total acreage and they are followed by Fluvisols (23.1\%), Haplic Luvisols (19.7\%) and Mollic Fluvisols (14.4\%). Regarding granularity these are medium heavy soils - loam $(83.6 \%)$ and partially sandy-loam (16.4\%). $94.1 \%$ of such soils occurs in lowland, $5.3 \%$ in moderate slopes. These soils are deep and without skeleton. Dominant soil-climatic region $(72.2 \%)$ is very warm, very dry lowland.

District of Košice $-9.3 \%$ of total agricultural soils area in Slovakia suitable for application of minimalizing technologies belongs to this district. Within the frame of this district agricultural soils suitable for application of minimalizing technologies presents about 
$19.0 \%$. Dominant soil type suitable for these technologies is Fluvisols, presenting 59.2\% from the total acreage and they are followed by, Haplic Luvisols (26.3\%) and Mollic Fluvisols (9.8\%). Regarding granularity these are medium heavy soils - loam $(85.7 \%)$ and partially sandy-loam (14.3\%). $92.3 \%$ of such soils occur in lowland. These soils are deep and without skeleton. Dominant soil-climatic region $(72.0 \%)$ is warm, very dry, continental plain.

District of Nitra $-43.3 \%$ of total agricultural soils area in Slovakia suitable for application of minimalizing technologies belongs to this district. Within the frame of this district agricultural soils suitable for application of minimalizing technologies presents about $64.0 \%$. Dominant soil type suitable for these technologies are Chernozems, presenting $40.9 \%$ from the total acreage and they are followed by Haplic Luvisols (24.9\%) and Regosols (16.7\%). Regarding granularity these are medium heavy soils - loam $(95.6 \%)$ and partially sandy-loam (4.4\%). $68.7 \%$ of such soils occur in lowland, $24.5 \%$ on moderate slopes. These soils are deep and without skeleton. Dominant soil-climatic region $(50.5 \%)$ is very warm, very dry lowland. Warm, very dry lowland region takes $43.6 \%$.

District of Prešov - $1.0 \%$ of total agricultural soils area in Slovakia suitable for application of minimalizing technologies belongs to this district. Within the frame of this district agricultural soils suitable for application of minimalizing technologies presents about $2.0 \%$. Dominant soil type suitable for these technologies are Fluvisols, presenting $82.1 \%$ from the total acreage of suitable soil and they are followed by Haplic Luvisols (9.0\%) and Albic Luvisols (8.7\%). Regarding granularity these are medium heavy soils - loam (67\%) and partially sandy-loamy (33\%). $89.6 \%$ of such soils occur in lowland, $7.6 \%$ on moderate slopes. These soils are deep and without skeleton. Dominant soil-climatic region $(72.6 \%)$ is warm, very dry, continental plain. Relatively warm, dry, basin-like, continental region takes $23.4 \%$.

District of Trenčín - 5.0\% of total agricultural soils area in Slovakia suitable for application of minimalizing technologies belongs to this district. Within the frame of this district agricultural soils suitable for application of minimalizing technologies presents about $18.5 \%$. Dominant soil type suitable for these technologies is Haplic Luvisols, presenting $41.4 \%$ from the total acreage of suitable soil and they are followed by Fluvisols (29.5\%) and Albic Luvisols (19.4\%). Regarding granularity these are medium heavy soils - loam (96.3\%) and partially sandy-loamy (3.7\%). $58.7 \%$ of such soils occur in lowland, $30.4 \%$ on moderate slopes. These soils are deep and without skeleton. Dominant soil-climatic region $(82.6 \%)$ is moderately

$\mathrm{T}$ a b 1 e 3

Contribution of soils suitable for minimalizing soil cultivating technologies in districts of Slovakia in \%

\begin{tabular}{|c|c|c|c|c|}
\hline \multirow[b]{2}{*}{$\begin{array}{l}\text { Territorial administrative } \\
\text { unit-district }\end{array}$} & \multicolumn{4}{|c|}{ Contribution of soils suitable for minimalizing soil cultivating technologies } \\
\hline & $\begin{array}{c}\text { from all agricultural } \\
\text { soils of Slovakia }\end{array}$ & $\begin{array}{c}\text { from suitable } \\
\text { agricultural soils of } \\
\text { Slovakia }\end{array}$ & $\begin{array}{c}\text { from agricultural soils } \\
\text { of the district }\end{array}$ & $\begin{array}{c}\text { from the arable land of } \\
\text { the district }\end{array}$ \\
\hline Bratislava & 1.5 & 5.3 & 38.7 & 49.0 \\
\hline Banská Bystrica & 2.6 & 9.4 & 15.5 & 38.9 \\
\hline Košice & 2.6 & 9.3 & 19.1 & 31.7 \\
\hline Nitra & 11.9 & 43.3 & 64.0 & 73.9 \\
\hline Prešov & 0.3 & 1.0 & 1.9 & 4.8 \\
\hline Trenčín & 1.4 & 5.0 & 18.5 & 35.1 \\
\hline Trnava & 7.3 & 26.7 & 63.1 & 70.2 \\
\hline Žilina & - & - & - & - \\
\hline
\end{tabular}


warm, dry, hilly. Warm, very dry, continental plain region takes $17.4 \%$.

District of Trnava $-26.7 \%$ of total agricultural soils area in Slovakia suitable for application of minimalizing technologies belongs to this district. Within the frame of this district agricultural soils suitable for application of minimalizing technologies presents about $63 \%$. Dominant soil type suitable for these technologies is Chernozems presenting $42.1 \%$ from the total acreage of suitable soil and they are followed by Haplic Luvisols (17.3\%), Fluvisols (14.5\%), Mollic Fluvisols (13.2\%) and Regosols (12.5\%). Regarding granularity these are medium heavy soils - loam (91.9\%) and partially sandy-loamy (8.1\%). $77.7 \%$ of such soils occur in lowland, $16.4 \%$ on moderate slopes. These soils are deep and without skeleton. Dominant soil-climatic region $(55.2 \%)$ is very warm, very dry lowland region. Warm, very dry lowland region takes $32.1 \%$ and a region moderately warm, dry, hilly takes $12.7 \%$.

District of Žilina - Likewise mountainous productive region soil-climatic conditions in this district are not suitable for application of minimalizing technologies. It does not mean that this way of cultivation is not possible to apply. If there are specific conditions, mostly regarding so called soil protective cultivation technologies (e. g. soil protection from erosion), it is possible to apply such systems for a short time.

Contribution of soils suitable for minimalizing soil cultivating technologies in districts of Slovakia is given in Table 3.

Contemporary knowledge on soil properties and their mapping and present technologies of relevant soilecological information processing enables each person interested in soil identification regarding soil availability for minimal processing to obtain such a piece of information via infoservice on soils of Slovakia. Above mentioned databases and a spatial specification in a vector form, is managed, via geographic informative systems (GIS), by Soil Science and Conservation Research Institute in Bratislava. The identification is possible on the strength of orthophotograph map of any land unit (parcel) of agricultural soil. An agriculturalist receives basic information in this way and he is informed if his site (a soil, a parcel) is suitable for minimalizing technologies and thus to make a decision for an optimal scenario of the soil cultivation.

\section{CONCLUSION}

Slovakia is a country with rich structure of natural varieties, with heterogenous climatic, geomorphologic, vegetation and pedologic conditions. This dynamics predetermines to utilize our areas in different ways, depending on their specifics. It is not possible to application a unified method for any activity in the country itself, mostly not in the agricultural country, where it is not possible to application automatically methods of neighbours, or of another regions. This concerns also the introduction of minimalizing soil cultivating and soil protective technologies.

Introduction of new soil cultivating technologies presents logical effort of agriculturalists to save costs connected with this activity. In recent years the method of minimalizing soil protective cultivation has become frequent.

Minimalizing soil cultivation technologies became popular in more companies. They are often use globally, without knowing the availability of the site for their application and without professional or practical experiences of the agriculturalists as well. The results of our investigation showed that the best assumptions for application of minimalizing soil cultivation technologies in maize productive area and according to administrative division is in Nitra region. Such technologies are not recommended for realization in mountainous productive area (Žilina region).

The ambition of the presented article is to offer information on soil suitability to all potential persons interested in minimalizing technologies.

Acknowledgement. This work was supported by the Slovak Research and Development Agency under contract No. APVV-0124-06 and Scientific Grant Agency of the Ministry of Education of the Slovak Republic and the Slovak Academy of Sciences under contract No. VEGA 1/0072/10.

\section{REFERENCES}

BIRKÁS, M. 2002. Környezetkímélö és energiatakarékos talajmüvelés [Environment conservation and energy saving tillage]. Gödöllő: Szent István Egyetem, 2002, 345 p. ISBN 963-9256-80-3.

DŽATKO, M. - SOBOCKÁ, J. 2009. Príručna pre použivanie máp pôdnoekologických jednotiek [Handbook for using the 
maps of soil-ecologic units]. Bratislava: VÚPOP, 2009, 102 p. ISBN 978-80-89128-55-6.

HUSNJAK, S. - FILIPOVIČ, D. - KOSUTIC, S. 2002. Influence of different tillage systems on soil physical properties and crop yield. In Rostlinná Výroba, vol. 48, 2002, no. 6, pp. $249-254$

HŮLA, J. - PROCHÁZKOVÁ, B. 2008. Minimalizace zpracování půdy [Minimalization of soil processing]. Praha: Profi press s.r.o., 248 p. ISBN 978-8086726-28-1.

JURÁŇ, C. 1997. Regionalizácia pôdnych jednotiek SSR z hl'adiska agrotechniky - minimalizácia obrábania a bezoreb$n y ́$ spôsob predsejbovej prípravy [Regionalization of soil units of SSR from agricultural engineering point of view - minimalization of cultivation and without ploughing way of pre-seeding preparation]. Bratislava: VÚPVR, 1979, 39 p.

KOVÁČ, K. - MACÁK, M. - ŠVANČÁRKOVÁ, M. 2005. The effect of soil conservation tillage on soil moisture dynamics under single and crop rotation. In Plant, Soil and Environment, vol. 51, 2005, no. 3, pp. 124-130.

KOVÁČ, K. - NOZDROVICKÝ, L. - MACÁK, M. et. al. 2010. Minimalizačné a pôdoochranné technológie [Minimalizing and soil protective technologies]. Nitra: Agroinštitút Nitra n.p., 2010, 142 p. ISBN 978-80-7139-139-5.

LOGSDON, S.D. - KARLEN, D.L. 2004. Bulk density as a soil quality indicator during conversion to no-tillage. In: Soil \& Tillage Research, vol. 78, 2004, no. 2, pp 143-149.

MACÁK, M. - LEHOCKÁ, Z. - ŽÁK, Š. - KOVÁČ, K. 2008. The effect of primary soil tillage and precipitation condition on soil bulk density. In Lucrari stiintifice, vol. 40, 2008, no. 2, pp. 93-98. ISSN 1221-5279.

MAZÚR, E. - LUKNIŠ, M. 1978. Regionálne geomorfologické členenie Slovenska [Regional geomorphological structuring of Slovakia]. In Goegrafický časopis, vol. 30, 1978, no. 2, pp. 101-124.

MIŠTINA, T. - KOVÁČ, K. 1993. Ochranné obrábanie pôdy [Protective soil tillage]. Pieštany: VÚRV Piešt'any, 1993, 167 p. ISBN 80-7137-125-4.
POSPIŠIL, R. - VILČEK, J. 2000. Energetika sústav hospodárenia na pôde [Energetics systems of soil management] Bratislava: VÚPOP, 2000, 108 p. ISBN 80-85361-75-2.

RŮŽEK, P. - KUSÁ, H. - MÜHLBACHOVÁ, G. 2000. Výživa a hnojení rostlin pri různych systémech zpracovaní půdy [Nutrition and fertilization of plants in different systems of soil cultivation]. In Využití různych systému zpracování půdy při pěstování rostlin [Nutrition and fertilization of plants in different systems of soil cultivation] : zborník z česko-slovenskej konference. Praha: VÚRV Praha, 2000. ISBN 80-238-5334-1, pp. 35-42.

SOBOCKÁ, J. et al. 2010. Návrh adaptačných opatrení na pôde pre zmiernenie úćinkov klimatickej zmeny [Suggestion of soil adaptation arrangements to moderate effects of climate change]. Bratislava: VÚPOP, 2010, 63 p. ISBN 978 $80891128-64-8$.

ŠIMON, J. - LHOTSKÝ, J. et al. 1989. Zpracování a zúrodňování půd [Soil tillage and fertilizing]. Praha: SZN, 1989, 317 p. ISBN 80-209-0048-9.

ŠIMON, J. - ŠKODA, V. - HŮLA, J. 1999. Zakladaní porostů hlavných polných plodín novými technológiami [Establishment of main crops stands by new technologies]. Praha: Agrospoj Těšnov, 1999, 78 p.

ŠVANČÁRKOVÁ, M. - LEHOCKÁ, Z. 2002. Biologické vlastnosti pôdy ovplyvnené bezorbovou technológiou obrábania [Biological soil properties affected by no-till technology]. In: Agriculture (Pol'nohospodárstvo), vol. 48, 2002, no. 6, pp. 313-318.

ŽÁK, Š. - KOVÁČ, K. - LEHOCKÁ, Z. 2002. Vplyv konvenčného a bezorbového obrábania pôdy v rôznych systémoch hospodárenia na bilanciu pôdnej organickej hmoty [The influence of conventional and no-till technology on soil organic matter balance in various arable farming systems]. In: Agriculture (Polnohospodárstvo), vol. 48, 2002, no. 9 , pp. $472-481$.

Received: October, $20^{\text {th }}, 2010$ 